\title{
A 2:2:2 Complex of Vanadium(V) with 4-(2-Thiazolylazo)orcinol and 2,3,5-Triphenyl-2H-Tetrazolium Chloride
}

\section{Kiril Blazhev Gavazov,* Vassil Borisov Delchev, Kremena Tomova Mileva, Teodora Stefcheva Stefanova and Galya Kostadinova Toncheva}

\author{
Faculty of Chemistry, University of Plovdiv "Paissii Hilendarski", 4000, Plovdiv, Bulgaria \\ *Corresponding author: E-mail: kgavazov@abv.bg \\ Tel.: +35932261425
}

Received: 15-03-2016

\begin{abstract}
Abstract. The complex formation in the vanadium(V) / 4-(2-thiazolylazo)orcinol (TAO) / 2,3,5-triphenyl-2H-tetrazolium chloride (TTC) liquid-liquid extraction-chromogenic system was studied. The chloroform-extracted complex has a composition of 2:2:2 under the optimum conditions ( $\mathrm{pH} 4.8-5.2$, extraction time 3 min, concentration of TAO $3.4 \times 10^{-4}$ mol dm${ }^{-3}$, and concentration of TTC $9.4 \times 10^{-4} \mathrm{~mol} \mathrm{dm}^{-3}$ ) and could be regarded as a dimer (D) of two 1:1:1 species (S) presented by the formula $\left(\mathrm{TT}^{+}\right)\left[\mathrm{VO}_{2}(\mathrm{TAO})\right]$. The constant of extraction was calculated by two methods and some analytical characteristics were determined. The wavelength of maximum absorption $\left(\lambda_{\max }\right)$, molar absorptivity $\left(\varepsilon_{\lambda}\right)$ and fraction extracted $(E)$ were found to be $\lambda=545 \mathrm{~nm}, \varepsilon_{545}=1.97 \times 10^{4} \mathrm{dm}^{3} \mathrm{~mol}^{-1} \mathrm{~cm}^{-1}$, and $E=97.9 \%$. The ground-state equilibrium geometries of the complexes $\mathrm{S}$ and $\mathrm{D}$ were optimized by quantum chemical Hartree-Fock calculations using $3-21 \mathrm{G}^{*}$ basis functions. The bonding and interaction energies were calculated as well.
\end{abstract}

Keywords: liquid-liquid extraction; spectrophotometry; tetrazolium salt; 5-methyl-4-(2-thiazolylazo)resorcinol; 2:2:2 complex; HF calculations.

\section{Introduction}

Vanadium is a trace element with many industrial applications. ${ }^{1}$ The recent interest in this element is also related to the observed beneficial role of its compounds for different aspects of human health. ${ }^{2-4}$ Complexes with various reagents have been proposed for determination of vanadium. ${ }^{5-7}$ However, the concentration of its species in environmental and biological samples is often lower than the corresponding limits of determination. A classical approach to solve this problem and improve the method's characteristics is to combine the instrumental method (e.g. spectrophotometry) with liquid-liquid extraction (LLE) - a simple technique for separation and preconcentration which does not require expensive equipment. $^{8}$

Among the complexes applied for vanadium LLEspectrophotometric determination and speciation of particular interest are these with participation of azocompounds (AC) and tetrazolium cations $\left(\mathrm{TZ}^{+}\right) .^{5,6,9,10}$ The fol- lowing ACs were investigated as components of ternary V(V)-AC-TZ complexes: 4-(2-pyridylazo)resorcinol ${ }^{10-12}$, 4-(2-thiazolylazo)resorcinol, ${ }^{13,14}$ and 4-(2-thiazolylazo)orcinol (TAO).$^{15}$ The obtained results show that the $\mathrm{V}(\mathrm{V})$ :AC molar ratio in these complexes differs, ${ }^{11-15}$ as a rule, from the typical 1:1 ratio established in the presence of other ion-association reagents (Table S1). However, the reason for this peculiarity is unclear and quantum-chemical calculations on V-AC-TZ ternary complexes have never been conducted.

In the light of this, the purpose of the current work is experimental (LLE-spectrophotometric) and theoretical (calculations at the HF/3-21G* level) study on the complexes formed between $\mathrm{V}(\mathrm{V}), 2,3,5$-triphenyl-2H-tetrazolium chloride (TTC) and TAO. Scarce information about the binary $\mathrm{V}(\mathrm{V})$-TAO complex in water-ethanol medium has been provided by Shalamova. ${ }^{16}$ TTC was selected for the present study because of its high application potential ${ }^{17-20}$ and recent interest to its ion-associates. ${ }^{21-26}$ 


\section{Experimental}

\section{1. Reagents and Apparatus}

- $\mathrm{NH}_{4} \mathrm{VO}_{3}$ (puriss. p.a., VEB Laborchemie Apolda) dissolved in doubly distilled water, $2 \times 10^{-4} \mathrm{~mol} \mathrm{dm}^{-3}$.

- TAO (95\%, Sigma-Aldrich Chemie $\mathrm{GmbH})$ dissolved in slightly alkalized (KOH) distilled water, $3 \times 10^{-3} \mathrm{~mol} \mathrm{dm}^{-3}$.

- TTC (p.a., Loba Feinchemie GMBH), $4.7 \times 10^{-3} \mathrm{~mol}$ $\mathrm{dm}^{-3}$ aqueous solutions.

- Ethanol (96\%).

- Chloroform (p.a.), additionally distilled.

- Acetate buffer solution prepared from $2 \mathrm{~mol} \mathrm{dm}^{-3}$ aqueous solutions of $\mathrm{CH}_{3} \mathrm{COOH}$ and $\mathrm{NH}_{4} \mathrm{OH}$. The resulting $\mathrm{pH}$ was checked by $\mathrm{HI}-83140 \mathrm{pH}$ meter.

- A Camspec M508 spectrophotometer (United Kingdom), equipped with $10 \mathrm{~mm}$ path-length cells.

\section{2. Procedure for Establishing the Optimum LLE-Spectrophotometric Conditions}

Aliquots of $\mathrm{V}(\mathrm{V})$ solution $\left(1 \mathrm{~cm}^{3}\right)$, TAO solution, buffer solution $\left(2 \mathrm{~cm}^{3}\right)$ and TTC solution were pipetted into $100 \mathrm{~cm}^{3}$ separatory funnels. The resulting solutions were diluted with distilled water to a total volume of $10 \mathrm{~cm}^{3}$. Then $10 \mathrm{~cm}^{3}$ of chloroform were added. The funnels were closed with stoppers and shaken for extraction. After separation of the layers, portions of the organic extracts were transferred through filter papers into cells. The absorbances were read against respective blank samples.

\section{3. Procedure for Determining the Complex Composition in Water-ethanol Medium}

$1 \mathrm{~cm}^{3}$ of $\mathrm{V}(\mathrm{V})$ solution, $\mathrm{i} \mathrm{cm}^{3}$ of TAO solution (i varies from 0.2 to $4 \mathrm{~cm}^{3}$ ), $2 \mathrm{~cm}^{3}$ of buffer solution ( $\mathrm{pH} 5.4$ ) and $3 \mathrm{~cm}^{3}$ of ethanol were added into test tubes with ground stoppers. The volumes were made up to $10 \mathrm{~cm}^{3}$ with distilled water. Then the tubes were closed and shaken for homogenization. Portions of the obtained solutions were transferred into cells. The absorbances were read against respective blank samples.

\section{4. Procedure for Determining the Distribution Coefficients}

The distribution coefficients $D=\Sigma c\left(\mathrm{~V}(\mathrm{~V})_{\text {org }}\right) /$ $\Sigma c\left(\mathrm{~V}(\mathrm{~V})_{\text {aq }}\right)$ were found from the ratio $D=A_{1} /\left(A_{3}-A_{1}\right)$, whe- re $A_{1}$ and $A_{3}$ are the absorbances (measured against blanks), obtained after a single and triple extractions, respectively. The single extraction and the first stage of the triple extraction were performed with $10 \mathrm{~cm}^{3}$ of chloroform under the optimum extraction-spectrophotometric conditions (Table 1). The organic layers were transferred into $25 \mathrm{~cm}^{3}$ calibrated flasks and the flask for the single extraction was brought to volume with chloroform. The second stage of the triple extraction was performed by adding a $7 \mathrm{~cm}^{3}$ portion of chloroform to the aqueous phase, which remained after the first stage. The third stage was performed in the same manner. The two successive organic layers were transferred to the flask containing the organic layer obtained after the first stage. The volume was brought to the mark with chloroform and shaken for homogenization. ${ }^{15,27,28}$

\section{Theoretical}

The ground-state equilibrium geometries of the single and dimeric complexes were optimized at the HF level using $3-21 \mathrm{G}^{*}$ basis functions. Their vibration spectra were calculated in order to check for imaginary frequencies (no such vibrational eigenvalues were calculated).

The stability of the complexes S and D was evaluated by the bonding and interaction energies found by the equations 1 and $2: 29-31$

$$
\begin{aligned}
& \Delta E_{b}=E_{S S}-\sum_{i} E_{i}^{\prime} \\
& \Delta E=E_{S S}-\sum_{i} E_{i}^{S P}
\end{aligned}
$$

where $\mathrm{E}_{\mathrm{SS}}$ is the energy of the given complex, whereas $E_{i}^{\prime}$ and $E_{i}^{S P}$ are the energies of the fragments found with 'ghost' orbitals and single-point calculations respectively with geometries as obtained by the optimizations. Thus, the basis-set superposition error (BSSE) was estimated by the equation 3 :

$$
\mathrm{BSSE}=\sum_{i}\left(E_{i}^{S P}-E_{i}^{\prime}\right)
$$

The theoretical calculations were performed with the GAUSSIAN 03 program package. The results were visualized with the ChemCraft program.

Table 1. Extraction-spectrophotometric optimization of the V(V)-TAO-TTC-water-chloroform system

\begin{tabular}{lccc}
\hline Parameter & Optimization range & Optimal value & Figure \\
\hline Wavelength, $\mathrm{nm}$ & Visible range & 545 & Fig. 1 \\
pH of the aqueous phase & $3.7-6.7$ & $4.8-5.2$ & Fig. 2 \\
Extraction time, min & $0.25-6$ & 3 & Fig. S1 \\
Concentration of TAO, mol dm & $(0.15-6.0) \times 10^{-4}$ & $3.4 \times 10^{-4}$ & Fig. 3 \\
Concentration of TTC, $\mathrm{mol} \mathrm{dm}^{-3}$ & $(0.24-14.1) \times 10^{-4}$ & $9.4 \times 10^{-4}$ & Fig. 3 \\
\hline
\end{tabular}




\section{Results and Discussion}

\section{1. Optimum LLE-spectrophotometric Conditions}

Absorption spectrum of the chloroform-extracted ternary complex is shown in Figure 1. The maximum is at $\lambda=$ $545 \mathrm{~nm}$. It is shifted to $5 \mathrm{~nm}$ as compared to the maximum of the binary $\mathrm{V}(\mathrm{V})-\mathrm{TAO}$ complex in water-ethanol medium $(\lambda=550 \mathrm{~nm})^{16}$ and practically coincides with that of other complexes of the type $\mathrm{V}(\mathrm{V})$-TAO-TZ in chloroform studied in our previous paper. ${ }^{15}$ It should be mentioned that the position of this maximum is constant independently of changes in $\mathrm{pH}$ and concentrations of the reagents. The optimum LLE-spectrophotometric conditions are given in Table 1. The optimization experiments included varying the $\mathrm{pH}$ (Figure 2), time of the extraction, and concentration of the reagents (Figure 3). The concentration of $\mathrm{V}(\mathrm{V})$ in the aque-

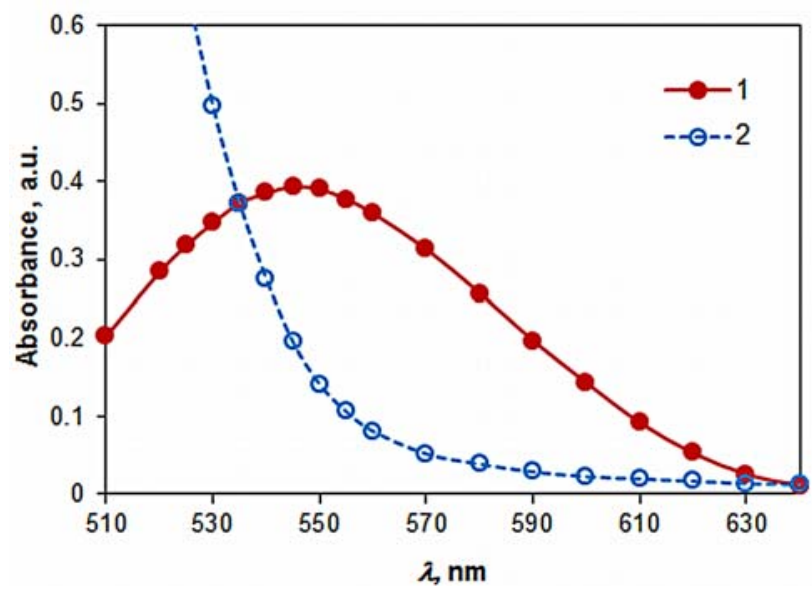

Figure 1. Absorption spectra of the ternary complex (curve 1) and blank (curve 2) in chloroform. $c_{\text {V(V) }}=2 \times 10^{-5} \mathrm{~mol} \mathrm{dm}^{-3}, c_{\mathrm{TAO}}=4.2$ $\times 10^{-4} \mathrm{~mol} \mathrm{dm}^{-3}, c_{\text {TTC }}=9.4 \times 10^{\mathrm{V}(\mathrm{V})} \mathrm{mol} \mathrm{dm}{ }^{-3}, \mathrm{pH} 5.0$.

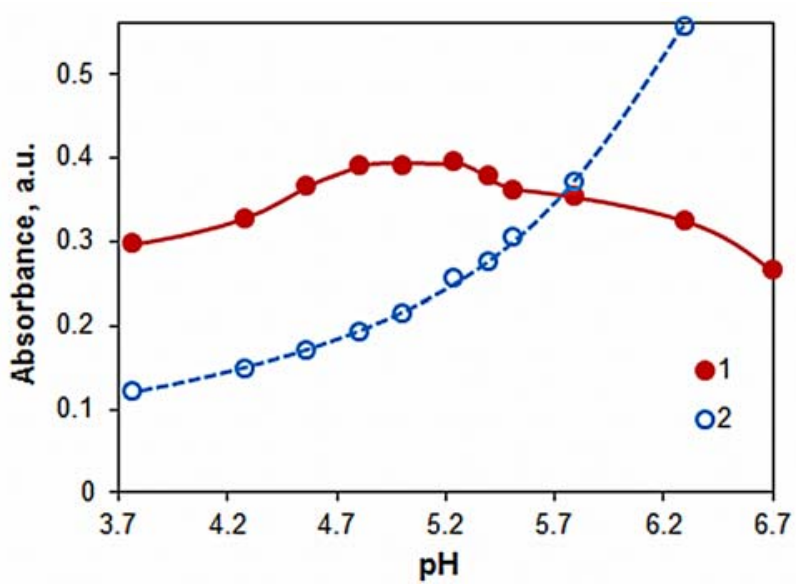

Figure 2. Absorbance of the complex (curve 1) and blank (curve 2) in chloroform vs $\mathrm{pH}$ of aqueous phase. $c_{\mathrm{WH}}=2 \times 10^{-5} \mathrm{~mol} \mathrm{dm}^{-3}$, $c_{\text {TAO }}=4.0 \times 10^{-4} \mathrm{~mol} \mathrm{dm}^{-3}, c_{\text {TTC }}=8.0 \times 10^{(-(4)} \mathrm{mol} \mathrm{dm}^{-3}, \lambda=545 \mathrm{~nm}$.

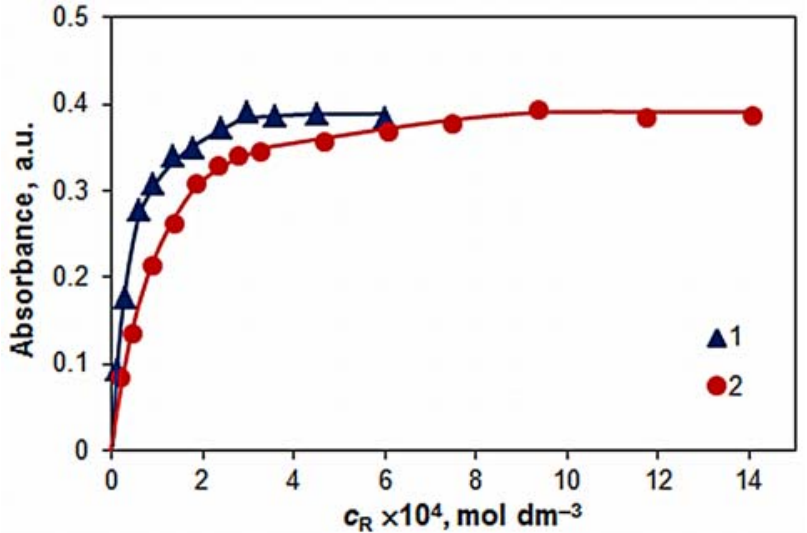

Figure 3. Absorbance of extracted complex vs concentration of the reagents (R): $1 . \mathrm{R}=\mathrm{TAO}, c_{\mathrm{N}}=2 \times 10^{-5} \mathrm{~mol} \mathrm{dm}^{-3}, c_{\mathrm{TTC}}=9.4 \times$ $10^{-4} \mathrm{~mol} \mathrm{dm}^{-3}, \mathrm{pH} 5.0, \lambda=545 \mathrm{~nm} ; 2 . \mathrm{R}=\mathrm{TTC}, c \stackrel{\mathrm{TTC}}{=} 2 \times 10^{-5}$ $\mathrm{mol} \mathrm{dm}{ }^{-3}, c_{\text {TAO }}=4.0 \times 10^{-4} \mathrm{~mol} \mathrm{dm}^{-3}, \mathrm{pH} 5.1, \lambda=545 \mathrm{~nm}$

ous phase was kept constant during the experiments $(2 \times$ $10^{-5} \mathrm{~mol} \mathrm{dm}^{-3}$ ); the temperature was $c a .22^{\circ} \mathrm{C}$.

\section{2. Composition, Formula and Equation}

The molar ratios of the components of the ternary complex, TAO: $\mathrm{V}(\mathrm{V})$ and TTC: $\mathrm{V}(\mathrm{V})$, were determined by the mobile equilibrium method (Figure 4) which is applicable for compounds of the type $\mathrm{A}_{\mathrm{n}} \mathrm{B}_{\mathrm{m}}$, where $n=m(n \geq$ 1). ${ }^{32}$ The slopes $a \pm \mathrm{SD}$ of the obtained straight lines for $n$ $=m=2$ (Figure 4) are close to 2:1.95 \pm 0.05 (straight line $1 ; \mathrm{R}=\mathrm{TAO}$ ) and $1.96 \pm 0.09$ (straight line $2 ; \mathrm{R}=\mathrm{TTC}$ ). At the same time, the corresponding slopes for $n=m=1$ $\{1.21 \pm 0.05(\mathrm{R}=\mathrm{TAO})$ and $1.20 \pm 0.04(\mathrm{R}=\mathrm{TTC})\}$ and $n=m=3\{2.69 \pm 0.10(\mathrm{R}=\mathrm{TAO})$ and $2.72 \pm 0.15(\mathrm{R}=$ TTC) $\}$ are far from 1 and 3 .

The TTC: $\mathrm{V}(\mathrm{V})$ molar ratio was determined by an independent method ${ }^{33}$ based on the effect of dilution on the

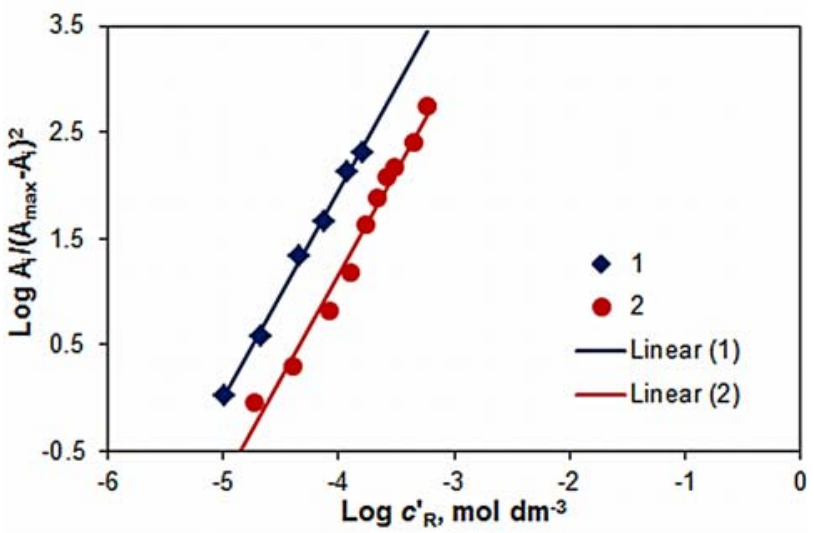

Figure 4. Determination of R-to- $\mathrm{V}(\mathrm{V})$ molar ratios by the mobile equilibrium method. The data are derived from the experimental points shown in Fig. 3. Straight line equations: (1) $y=1.95 x+9.75$ $\left(\mathrm{R}=\mathrm{TAO}, r^{2}=0.9974\right) ;(2) y=1.96 x+8.98\left(\mathrm{R}=\mathrm{TTC}, r^{2}=0.9824\right)$ 
degree of dissociation. The experimental points (Figure 5) determine a straight line for TTC: $\mathrm{V}(\mathrm{V})=2: 2(y=-3433 x+$ $\left.2587 ; r^{2}=0.9978\right)$ and a curve for TTC: $\mathrm{V}(\mathrm{V})=1: 1$. Therefore, the results of both methods agree well. They show that the complex has a composition of 2:2:2. Its formation and extraction can be represented with equation 4 , which is consistent with the state of $\mathrm{V}(\mathrm{V})^{7}$ and $\mathrm{TAO}^{34}$ at the working conditions $\left(\mathrm{pH}_{\text {opt }}\right.$ and $\left.c_{\mathrm{V}(\mathrm{V})}\right)$. We believe that $\mathrm{V}(\mathrm{V})$ does not change its oxidation state during the complex formation. ${ }^{9-15}$

$$
\begin{aligned}
& 2 \mathrm{H}_{2} \mathrm{VO}_{4}^{-}{ }_{(\mathrm{aq})}^{-}+2 \mathrm{H}_{2} \mathrm{TAO}_{(\mathrm{aq})}+2 \mathrm{TT}^{+} \\
& \rightleftarrows\left(\mathrm{aq}^{+}\right) \\
& \rightleftarrows\left(\mathrm{TO}_{2}(\mathrm{TAO})\right]_{2(\mathrm{o})}+4 \mathrm{H}_{2} \mathrm{O}_{(\mathrm{aq})}
\end{aligned}
$$

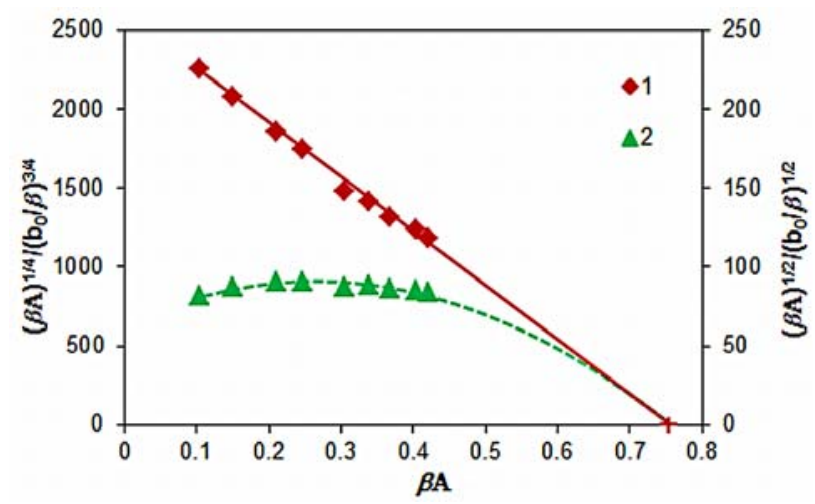

Figure 5. A straight line (1; molar ratio of 2:2, left ordinate) and a curve (2; molar ratio of $1: 1$, right ordinate) obtained by the dilution method. $c_{\mathrm{V}(\mathrm{V})}=c_{\mathrm{TTC}}, c_{\mathrm{TAO}}=3.4 \times 10^{-4} \mathrm{~mol} \mathrm{dm}^{-3}, \mathrm{pH} 5.2, \lambda=545 \mathrm{~nm}$

\section{3. Constant of Extraction and Fraction Extracted}

The constant of extraction was calculated by two methods: the dilution method ${ }^{33}$ (Figure 5) and the Likus-

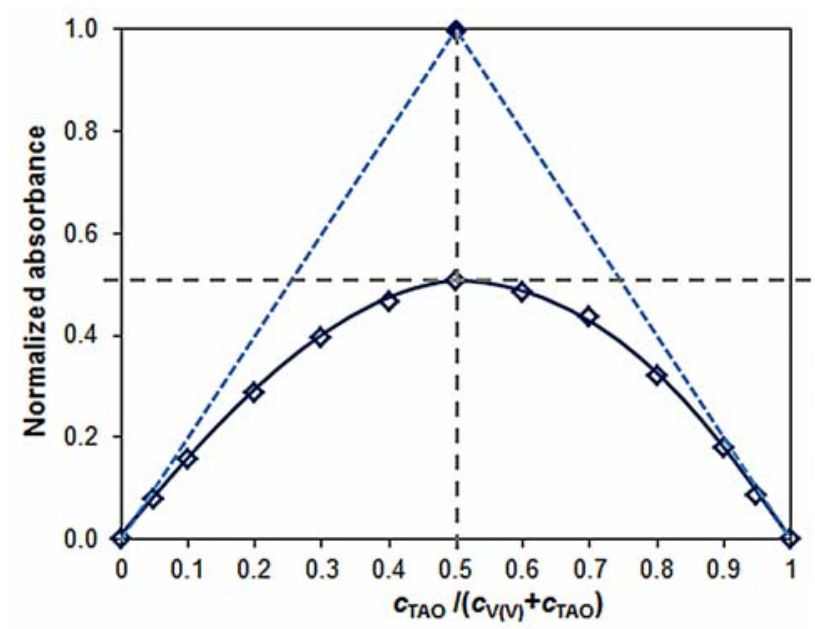

Figure 6. Determination of the constant of extraction $\left(K_{\mathrm{ex}}\right)$ by the Likussar-Boltz method at $k=c_{\mathrm{V}(\mathrm{V})}+c_{\mathrm{TAO}}=1 \times 10^{-4} \mathrm{~mol} \mathrm{dm}^{-3} \cdot c_{\mathrm{TTC}}=$ $9.4 \times 10^{-4} \mathrm{~mol} \mathrm{dm}^{-3}, \mathrm{pH} 5.2$.
sar-Boltz method ${ }^{35}$ (Figure 6), extended by the equation 5 , proposed in our previous paper ${ }^{15}$ for this kind of complexes.

$$
K_{\mathrm{ex}}=0.0625 \times(4 / \mathrm{k})^{3} \times \mathrm{y}_{\max } \times\left(1-\mathrm{y}_{\max }\right)^{-4}
$$

The corresponding values agree very well: $\log K_{\mathrm{ex}}=$ $13.47 \pm 0.02$ and $\log \mathrm{K}_{\mathrm{ex}}=13.53 \pm 0.05$.

The fraction extracted was calculated by the formula $E \%=100 \times D_{\mathrm{v}(\mathrm{V})} /\left(D_{\mathrm{v}(\mathrm{V})}+1\right)$, were $D_{\mathrm{v}(\mathrm{V})}$ is the distribution coefficient for the optimum extraction conditions. The following value was obtained: $E=(97.9 \pm 0.1) \%$. $D_{\mathrm{v}(\mathrm{V})}$ was found by comparison of the absorbance values obtained after single and triple extractions: $D_{\mathrm{V}(\mathrm{V})}=46 \pm 2$ (4 replicate experiments).

\section{4. Analytical Characteristics}

The dependence between the concentration of $\mathrm{V}(\mathrm{V})$ and the absorbance of the extracted complex was studied under the optimum conditions (Table 1). A very good linearity was obtained in the concentration range of 0.2-4.6 $\mu \mathrm{g} \mathrm{cm}{ }^{-3}\left(r^{2}=0.9998, N=8\right)$ (Figure S2). The linear regression equation was $A=0.399 \gamma-0.0076$, where $A$ is the absorbance and $\gamma$ is the concentration of $\mathrm{V}(\mathrm{V})(\mu \mathrm{g}$ $\mathrm{cm}^{-3}$ ). The standard deviations of the slope and intercept were 0.002 and 0.005 , respectively. The limits of detection (LOD) and quantitation (LOQ), calculated as 3 and 10 times standard deviation of the intercept divided by the slope, were $\mathrm{LOD}=0.04 \mu \mathrm{g} \mathrm{cm}^{-3}$ and $\mathrm{LOQ}=0.14 \mu \mathrm{g} \mathrm{cm}^{-3}$. The molar absorptivity $(\varepsilon)$ and Sandell's sensitivity $(S S)$ were $\varepsilon_{545}=1.97 \times 10^{4} \mathrm{dm}^{3} \mathrm{~mol}^{-1} \mathrm{~cm}^{-1}$ and $S S_{545}=2.6 \times$ $10^{-3} \mu \mathrm{g} \mathrm{cm}{ }^{-2}$, respectively.

\section{5. Composition of the Binary V-TAO Complex in Water-ethanol Medium}

Shalamova ${ }^{16}$ provides the following scarce information about the binary $\mathrm{V}(\mathrm{V})-\mathrm{TAO}$ complex in water-ethanol medium: $\mathrm{pH}_{\text {opt }}=5.0-5.5, \lambda_{\text {max }}=540 \mathrm{~nm}$, and $\varepsilon_{\text {max }}=1.3 \times$ $10^{4} \mathrm{dm}^{3} \mathrm{~mol}^{-1} \mathrm{~cm}^{-1}$. There is no information about the composition of the complex.

In order to fill this gap we used the method of Asmus $^{36}$ (Figure S3) and the mobile equilibrium method ${ }^{32}$ (Figure S4). The results show that the molar ratio between the reacting TAO and $\mathrm{V}(\mathrm{V})$ is $1: 1$ (not 2:2).

\section{6. Optimized Ground-state Equilibrium Geometries}

The ternary complex has a composition of 2:2:2 and can be regarded as obtained by dimerization of two 1:1:1 (V:PAR:TT) single complexes (see Table S1 and Refs. S10-S18).

Single complexes. The optimized ground-state equilibrium geometries of two possible single complexes $\mathbf{S 1}$ 
and $\mathbf{S 2}$ are illustrated in Figure 7. For the optimization of the first structure (S1) we started from a T-shaped structure between the anionic and cationic parts, $\left[\mathrm{VO}_{2}(\mathrm{TAO})\right]^{-}$ and $\mathrm{TT}^{+}$, respectively. The tetrazolium ring was initially located over the deprotonated $\mathrm{O}(8)$ atom. The T-shape was changed during the fully-relaxed optimization but the close distance between $\mathrm{O}(8)$ and the tetrazolium ring was kept: e.g. the distance $\mathrm{O}(8) \cdots \mathrm{N}(28)=3.501 \AA$. Two close interactions are observed between the fragments 1 and 2 in the complex S1. They are two weak H-bonds between the benzene ring hydrogens and the oxygen atoms of the fragment 1: $\mathrm{H}(64) \cdots \mathrm{O}(7)=2.460 \AA$ and $\mathrm{H}(63) \cdots \mathrm{O}(18)=$ $2.189 \AA$. These bonds cause a interring twist between the tetrazolium and benzene residues: $\angle \mathrm{C}(45) \mathrm{C}(33) \mathrm{C}(30) \mathrm{N}(29)$ $=30.8^{\circ}$, however $\angle \mathrm{C}(39) \mathrm{C}(34) \mathrm{N}(28) \mathrm{N}(29)=-83.3^{\circ}$ and $<\mathrm{C}(35) \mathrm{C}(34) \mathrm{N}(28) \mathrm{N}(29)=94.8^{\circ}$.

In Fig. $7 b$ is depicted the optimized ground-state structure of the single complex S2. In this structure the oxygen atom $\mathrm{O}(18)$ which is bound to vanadium is directed to the tetrazolium ring. As a result, this atom and the atoms from the tetrazolium ring form pentagonal pyramid, whose vertex is the $\mathrm{O}(18)$ atom. This kind of interaction between the complex anion and the $\mathrm{TT}^{+}$part of the single complex leads to a slight reduction $(0.054 \AA)$ of the distance $\mathrm{V}(17) \cdots \mathrm{N}(9)$ as compared to the single complex

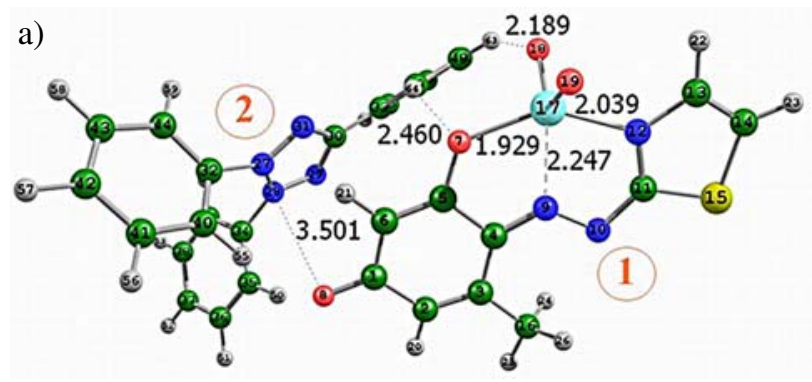

b)

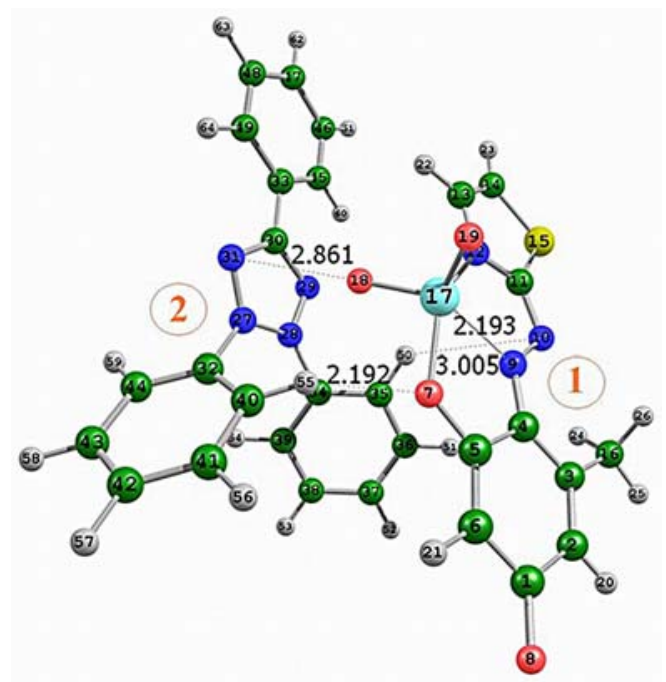

Figure 7. Optimized ground-state equilibrium geometries of the single complexes. a) S1 b) S2.
S1. Moreover, in the complex $\mathbf{S 2}$ the bonds $\mathrm{O}(7)-\mathrm{V}(17)$ and $\mathrm{V}(17)-\mathrm{N}(12)$ are $0.034 \AA$ and $0.015 \AA$ shorter than these in the complex S1. All this indicates, from a structural point of view, that the complex anion in the $\mathbf{S 2}$ system should be a bit more stable than this in the ion-association system S1.

With respect to the cationic part of the complex $\mathbf{S 2}$ one can say that one of the benzene rings is almost conjugated with the tetrazolium ring (located in one plane): $\angle \mathrm{C}(45) \mathrm{C}(33) \mathrm{C}(30) \mathrm{N}(29)=2.5^{\circ}$. The remaining two benzene rings are located with respect to the tetrazolium ring almost like in the ion-association single complex S1: $<\mathrm{C}(39) \mathrm{C}(34) \mathrm{N}(28) \mathrm{N}(29)=-132.2^{\circ}$ and $<\mathrm{C}(35)$ $\mathrm{C}(34) \mathrm{N}(28) \mathrm{N}(29)=46.8^{\circ}$

Dimer. In Figure 8 is depicted the optimized ground-state structure of the dimer $\mathbf{D}$. We believe that in the non-polar media (chloroform) the most probable dimeric structure would be from the type $\left(\mathrm{TT}^{+}\right)$$\left(\mathrm{VO}_{2} \mathrm{TAO}^{-}\right) \cdots\left(\mathrm{VO}_{2} \mathrm{TAO}^{-}\right)-\left(\mathrm{TT}^{+}\right)$, forming some kind of a sandwich aggregate. The attempts to find a structure which is analogue to the single complex $\mathbf{S 2}$ failed. The optimization of such structure led to the dimer $\mathbf{D}$, which seems to be the only stable sandwich aggregate.

The structure of the supersystem D shows two Hbonds between $\mathrm{O}(8) / \mathrm{O}(72)$ and the hydrogens from the two neighbouring benzene rings: $\mathrm{O}(8) \cdots \mathrm{H}(50)=2.011 \AA$, $\mathrm{O}(8) \cdots \mathrm{H}(55)=1.997 \AA, \mathrm{O}(72) \cdots \mathrm{H}(119)=2.014 \AA$, $\mathrm{O}(72) \cdots \mathrm{H}(114)=1.991 \AA$. The two complex anions in the dimer $\mathbf{D}$ are almost parallel one to another. The average distance between the planes of the two complex anions is about $4 \AA$.

With respect to the coordination bonds around the vanadium atom, one can say that only minor changes are observed between the single complex $\mathbf{S 1}$ and the dimer $\mathbf{D}$. For example, the distance $\mathrm{N}(9)-\mathrm{V}(17)$ is almost the same (difference only $0.001 \AA$ ), the bond $\mathrm{V}(17)-\mathrm{O}(7)$ is a bit shorter $(0.014 \AA)$ in the aggregate $\mathbf{D}$ than in the single complex S1, whereas the bond $\mathrm{N}(12)-\mathrm{V}(17)$ is $0.008 \AA$ longer in the system $\mathbf{D}$.

Minor differences in the bond lengths were also found between the same distances from the two complex cations in the dimer $\mathbf{D}$ : the distance $\mathrm{N}(9)-\mathrm{V}(17)$ in the fragment 1 (with a smaller labelling of the atoms) is 0.006 $\AA$ shorter than the distance $\mathrm{N}(73)-\mathrm{V}(81)$ in the fragment 2 (with a larger labelling of the atoms); the bond lengths $\mathrm{O}(7)-\mathrm{V}(17)$ and $\mathrm{O}(71)-\mathrm{V}(81)$ are almost identical (difference only $0.001 \AA$ ); the bond length $\mathrm{N}(12)-\mathrm{V}(17)$ in the fragment 1 is only $0.007 \AA$ longer than the distance $\mathrm{N}(76)-\mathrm{V}(81)$ in the fragment 2 . These slighting differences are due probably to the different orientation of the anionic parts of the fragments with respect to the cationic ones.

It should be mentioned that the weak $\mathrm{H}$-bonds between one of the oxygen atoms of the $\mathrm{VO}_{2}$ groups and hydrogen atoms from the $\mathrm{CH}_{3}$-groups of TAO probably significantly affect the overall stability of $\mathbf{D}$ : 


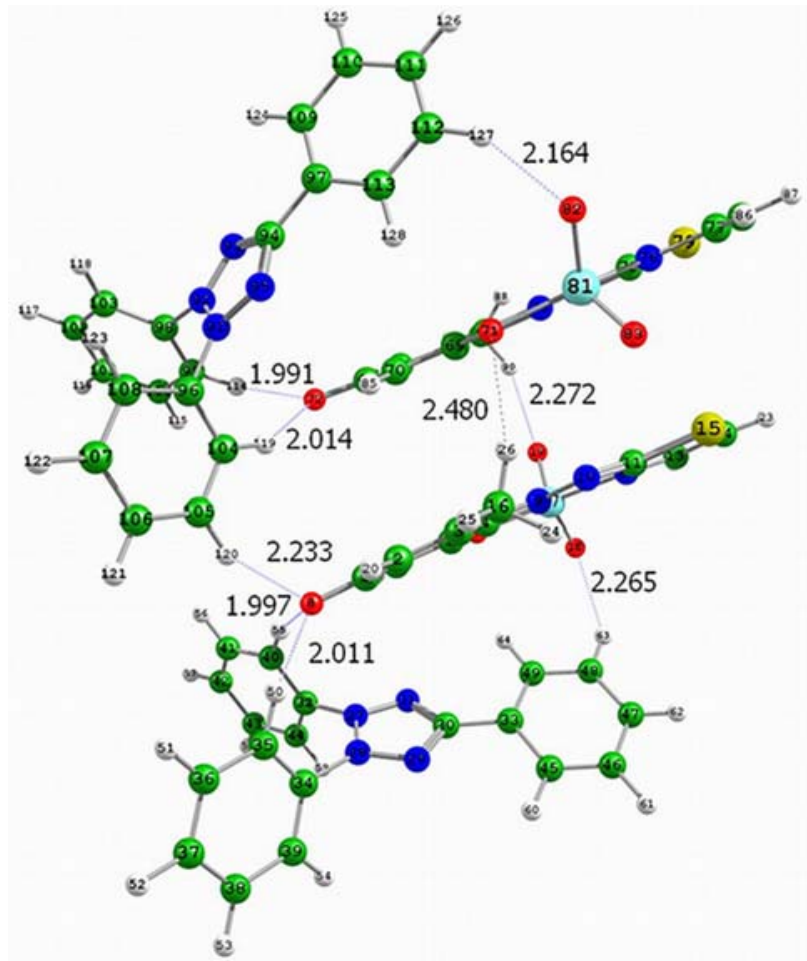

Figure 8. Optimized ground-state equilibrium geometry of the dimer $\mathbf{D}$.

$\mathrm{O}(19) \cdots \mathrm{H}(90)=2.272 \AA$ and $\mathrm{O}(71) \cdots \mathrm{H}(26)=2.480 \AA$. The existence of these bonds is a good explanation of the observed difference in the composition of the complex studied in this paper (V:TAO:TTC $=2: 2: 2$ ) and the similar complex with 4-(2-thiazolylazo)resorcinol (TAR) (V:TAR:TTC $=1: 2: 3) .{ }^{14}$ Such bonds do not exist in the $\mathrm{V}(\mathrm{V})$-TAR-TTC complex since there is no $\mathrm{CH}_{3}$-groups in the TAR molecule.

\section{7. Bonding and Interaction Energies}

The calculated bonding and interaction energies of the single complexes $\mathbf{S 1}$ and $\mathbf{S 2}$ and the dimer aggregate $\mathbf{D}$ are listed in Table 2. As seen, the bonding and the interaction energies of the single complexes have high negative values. They show that the single ion-association complexes are stable. Comparing the systems $\mathbf{S 1}$ and $\mathbf{S 2}$ one can see that the complex $\mathbf{S 1}$ is more stable than the complex S2. The bonding energy of the dimer system $\mathbf{D}$ is positive which means that the formation of this aggregate in the gas phase is not favoured despite the negative value of the interaction energy for it. The BSSE values are almost equal for all systems.

\section{Conclusion}

Vanadium(V) forms a well chloroform-extractable complex with TAO and TTC. It has a composition of 2:2:2 and can be regarded as a dimer of two 1:1:1 complex species. The structure, stability, and other characteristics of the dimer and its constituent parts were found. The constant of extraction, fraction extracted, molar absorptivity, Sendall's sensitivity, limit of detection, and limit of determination were determined as well. The obtained results shed light on an insufficiently explored area of the chemistry of the ion-association complexes of vanadium.

\section{Acknowledgements}

This work was supported by the Research Fund of the University of Plovdiv "Paisii Hilendarski" (Grant No NI15-HF-001).

\section{Supplementary Material}

Supplementary Material (Figures S1-S4 and Table 1S) are available electronically on the Journal's web site.

\section{References}

1. K. K. Chatterjee, Uses of Metals and Metallic Minerals, New Age International (P) Ltd. Publishers, New Delhi, India, 2007, pp. 272-275

2. K. Gruzewska, A. Michno, T. Pawelczyk, H. Bielarczyk, J. Physiol. Pharmacol. 2014, 65, 603-611.

3. D. Rehder, Met. Ions Life Sci. 2013, 13, 139-169. http://dx.doi.org/10.1007/978-94-007-7500-8_5

4. A. Srivastava, Mol. Cell. Biochem. 2000, 206, 177-182. http://dx.doi.org/10.1023/A:1007075204494

5. K. Pyrzyñska, T. Wierzbicki, Talanta 2004, 64, 823-829. http://dx.doi.org/10.1016/j.talanta.2004.05.007

6. K. Pyrzyñska, Microchim. Acta 2005, 149, 159-164. http://dx.doi.org/10.1007/s00604-004-0304-5

Table 2. Energies (in a.u.) and bonding, and interaction energies of the single complexes $\mathbf{S 1}$ and $\mathbf{S 2}$ and of the dimeric aggregate $\mathbf{D}$ (in $\mathrm{kJ} \mathrm{mol}^{-1}$ )

\begin{tabular}{|c|c|c|c|c|}
\hline Complex & E / a.u. & $\Delta \mathrm{E}_{\mathrm{b}} / \mathrm{kJ} \mathrm{mol}^{-1}$ & $\Delta \mathrm{E} / \mathrm{kJ} \mathrm{mol}^{-1}$ & BSSE / kJ mol ${ }^{-1}$ \\
\hline$\overline{\text { S1 }}$ & -3115.471055 & -267.5 & -328.6 & 61.1 \\
\hline S2 & -3115.468137 & -242.6 & -308.7 & 66.1 \\
\hline D & -6230.955679 & 19.7 & -50.0 & 69.8 \\
\hline
\end{tabular}

Gavazov et al.: A 2:2:2 Complex of Vanadium(V) ... 
7. M. J. C. Taylor, J. F. Staden, Analyst 1994, 119, 1263-1276. http://dx.doi.org/10.1039/an9941901263

8. Z. Marczenko, M. Balcerzak, Separation, preconcentration and spectrophotometry in inorganic analysis, Elsevier, Amsterdam - Lausanne - New York - Oxford - Shannon - Tokyo, 2000.

9. K. B. Gavazov, Z. Simeonova, A. Alexandrov, Talanta 2000, 52, 539-544. http://dx.doi.org/10.1016/S0039-9140(00)00405-7

10. T. S. Stefanova, K. K. Simitchiev, K. B. Gavazov, Chem. Pap. 2015, 69, 495-503. http://dx.doi.org/10.1515/chempap-2015-0048

11. L. M. Dimova, E. A. Morgen, Zavod. Lab. 1984, 50, 7-9

12. K. B. Gavazov, V. D. Lekova, G. I. Patronov, Acta Chim. Slov. 2006, 53, 506-511.

13. K. B. Gavazov, V. D. Lekova, A. N. Dimitrov, G. I. Patronov, Cent. Eur. J. Chem. 2007, 5, 257-270.

14. K. Gavazov, Z. Simeonova, University of Plovdiv "Paissii Hilendarski”-Bulgaria, Scientific works. Chemistry 2004, 32, 15-20.

15. K. B. Gavazov, T. S. Stefanova, Croat. Chem. Acta 2014, 87, 233-240. http://dx.doi.org/10.5562/cca2436

16. G. G. Shalamova, Tr. Perm. Med. Inst. 1972, 108, 48-53.

17. D. S. Daniel, in: R. Muthyala (Ed.): Chemistry and Applications of Leuco Dyes, Kluwer Academic Publishers, New York - Boston - Dordrecht - London - Moscow, 2002, pp. 207-296. http://dx.doi.org/10.1007/0-306-46906-5_7

18. R. W. Sabnis, Handbook of biological dyes and stains: synthesis and industrial applications, Wiley, Hoboken, US, 2010, pp. 485-487. http://dx.doi.org/10.1002/9780470586242

19. A. K. Pikaev, Z. K. Kriminskaya, Russ. Chem. Rev. 1998, 67, 671-680.

http://dx.doi.org/10.1070/RC1998v067n08ABEH000392
20. K. B. Gavazov, A. N. Dimitrov, A. N., V. D. Lekova, Russ. Chem. Rev. 2007, 76, 169-179. http://dx.doi.org/10.1070/RC2007v076n02ABEH003655

21. K. Nakashima, N. Kawame, Y. Kawamura, O. Tamada, J. Yamauchi, Acta Cryst. 2009, E65, m1406-m1407.

22. M. Gjikaj, T. Xie, W. Brockner, Z. Anorg. Allg. Chem. 2009, 635, 2273-2278. http://dx.doi.org/10.1002/zaac.200900174

23. T. Xie, W. Brockner, M. Gjikaj, Z. Naturforsch., B: Chem. Sci. 2009, 64, 989-994.

24. A. S. Bashammakh, E-J. Chem. 2011, 8, 1462-1471.

25. H.-K. Fun, T. S. Chia, G. A. Mostafa, M. M. Hefnawy, H. A. Abdel-Aziz, Acta Cryst. 2012, E68, o2567-o2567.

26. N. H. Buttrus, J. M. Alyass, A. F. Mohammad, J. Chem. Chem. Eng. 2013, 7, 613-620.

27. V. V. Divarova, V. D. Lekova, P. V. Racheva, K. T. Stojnova, A. N. Dimitrov, Acta Chim. Slov. 2014, 61, 813-818.

28. K. T. Stojnova, K. B. Gavazov, D. Lekova, Acta Chim. Slov. 2013, 60, 390-396.

29. S. F. Boys, F. Bernardi, Mol. Phys. 1970, 19, 553-566. http://dx.doi.org/10.1080/00268977000101561

30. P. Hobza, R. Zahradnik, Mezhmolekulyarnye kompleksy, Mir, Moscow, Russia, 1989.

31. S. Simon, M. Duran, J. Dannenberg, J. Phys. Chem. A 1999, 103, 1640-1643. http://dx.doi.org/10.1021/jp9842188

32. Z. Zhiming, M. Dongsten, Y. Cunxiao, J. Rare Earths 1997, 15, 216-219.

33. T. R. Galan, A. A. Ramirez, M. R. Ceba, Talanta 1980, 27, 545-547. http://dx.doi.org/10.1016/0039-9140(80)80080-4

34. N. Menek, E. Eren, S. Topçu, Dyes Pigm. 2006, 68, 205-210. http://dx.doi.org/10.1016/j.dyepig.2005.01.010

35. W. Likussar, D. F. Boltz, Anal. Chem. 1971, 43, 1265-1272. http://dx.doi.org/10.1021/ac60304a006

36. E. Asmus, Fresenius J. Anal. Chem. 1960, 178, 104-116. http://dx.doi.org/10.1007/BF00467200

\section{Povzetek}

Tvorba kompleksa v vanadij(V) / 4-(2-tiazolilazo)orcinol (TAO) / 2,3,5-trifenil-2 $H$-tetrazolijev klorid (TTC) tekočina-tekočina ekstrakcijskem sistemu je bila proučevana. S kloroformom ekstrahirani kompleks ima sestavo 2:2:2 pri optimalnih pogojih ( $\mathrm{pH} 4.8-5.2$, ekstrakcijski čas 3 min, koncentracija TAO $3.4 \times 10^{-4} \mathrm{~mol} \mathrm{dm}^{-3}$ in koncentracija TTC $9.4 \times 10^{-4} \mathrm{~mol} \mathrm{dm}^{-3}$ ) in ga lahko smatramo kot dimer (D) dveh 1:1:1 zvrsti (S) s formulo $\left(\mathrm{TT}^{+}\right)\left[\mathrm{VO}_{2}(\mathrm{TAO})\right]$. Konstanta ekstrakcije je bila izračunana $\mathrm{z}$ uporabo dveh metod in nekaj analitskih karakteristik je bilo določenih. Absorpcijski maksimum $\left(\lambda_{\max }\right)$, molska absorptivnost $\left(\varepsilon_{\lambda}\right)$ in izkoristek ekstrakcije $(E)$ so $\lambda=545 \mathrm{~nm}, \varepsilon_{545}=1.97 \times 10^{4} \mathrm{dm}^{3} \mathrm{~mol}^{-1}$ $\mathrm{cm}^{-1}$ in $E=97.9 \%$. Osnovna stanja geometrij $\mathrm{S}$ in $\mathrm{D}$ v ravnotežju so bila optimizirana s pomočjo Hartree-Fock kvantnomehanskih izračunov z uporabo 3-21G* baznih funkcij. Izračunane so bile tudi vezne in interakcijske energije. 